\title{
Public-sector entrepreneurship
}

By: Christopher S. Hayter, Albert N. Link, and John T. Scott

This is a pre-copyedited, author-produced version of an article accepted for publication in Oxford Review of Economic Policy following peer review. The version of record

Hayter, C.S., Link, A.N., \& Scott, J.T. Oxford Review of Economic Policy, 2018, 34(4): 676-694. https://doi.org/10.1093/oxrep/gry014

is available online at: https://doi.org/10.1093/oxrep/gry014

***(C) 2018 The Authors. Reprinted with permission. No further reproduction is authorized without written permission from Oxford University Press. This version of the document is not the version of record. $* * *$

\begin{abstract}
:
We define public-sector entrepreneurship as having three distinct components: actions that are innovative, that transform a status quo social and economic environment, and that are characterized by uncertainty. While the literature on public-sector entrepreneurship dates to the mid-1960s, the scholarly foundations on which public-sector entrepreneurship is based date to the writings of Cantillon and Baudeau in the mid- and late-1700s and to Schumpeter in the late1930s and early-1940s. After summarizing the academic and policy literatures on public-sector entrepreneurship, we illustrate the concept using examples of public-sector initiatives. We conclude the paper with an emphasis on the dynamic nature of public-sector entrepreneurship, and we offer insight into additional areas to which the concept applies as well as policy suggestions for incentivizing further public-sector entrepreneurial actions.
\end{abstract}

Keywords: entrepreneur | public sector | innovative | uncertainty

\section{Article:}

\section{Introduction}

The title of this paper has two parts: public sector and entrepreneurship. It is important to define both parts of the title in an effort to frame our discussion about the concept of public-sector entrepreneurship. Regarding our use of the term public sector, the examples in the following sections of this paper relate to public-sector initiatives in North America, although the concept of public-sector entrepreneurship is applicable internationally. We use the term entrepreneurship to refer to those activities in the public sector that involve both perception and action. To embrace fully the concept of public-sector entrepreneurship, perception and action need to be understood as a dynamic functional concept and not as a static or descriptive one.

Our coupling of the terms public sector and entrepreneurship may create dissonance because much of the academic literature on entrepreneurship involves private-sector actors. Markets 
operate through the laws of supply and demand, and entrepreneurial actors within markets respond to explicit and implicit prices to maximize profits. A profit-maximizing response has positive and normative implications for the outcomes of private-sector markets. This is not to say that public-sector actors never engage in private-sector market activity; it is also not to say that those actors do not directly or indirectly influence market activity. What makes the public sector entrepreneurial is that it can be associated with the recognition and exploitation of new opportunities, and thus its actions are characterized by uncertainty.

The remainder of this paper is outlined as follows. In section II, we briefly overview the elements of classical concepts of entrepreneurship that relate to public-sector behaviour, and we then suggest that public-sector entrepreneurship is a lens through which to view public initiatives that, like many entrepreneurial actions, alter the status quo social and economic environment to bring about creative change. Section II concludes with a formal definition of public-sector entrepreneurship.

In section III, we review the literature on public-sector entrepreneurship from several dimensions: the academic discipline of the authors of the scholarship that we review, the motivations ascribed to the public-sector entrepreneur, and the intended outcomes of the actions of the entrepreneurial process. The literature on public-sector entrepreneurship typically refers to the public-sector entrepreneur who acts entrepreneurially as a single individual. However, the concept of public-sector entrepreneurship is a multi-level concept that can also refer to the organizational and policy-level actions. That is the case in the examples we describe in section IV.

In section IV, we describe several public-sector initiatives that can be characterized in terms of public-sector entrepreneurship. These are the Saving Brains Grand Challenge Program in Canada, the Government Performance and Results Act (GPRA) in the United States, the US Bayh-Dole Act and the Stevenson-Wydler Technology Innovation Act, and the establishment of the US Small Business Innovation Research (SBIR) programme.

Concluding remarks are offered in section V. There, we not only summarize our labelling of specific policy initiatives as examples of public-sector entrepreneurship, but we also suggest a policy action that might engender ongoing public-sector entrepreneurship.

\section{Classical concepts of entrepreneurship}

As a foundation for discussing the concept of public-sector entrepreneurship, it is important to embrace the concept of entrepreneurship from a dynamic perspective. As discussed by Hébert and Link (2009), dynamic views of entrepreneurship trace to the writings of Richard Cantillon (1680-1734) and Abbé Nicolas Baudeau (1730-92), among others.

Cantillon characterized the entrepreneur as the central figure in the private-sector marketplace who, through creativity and through a willingness to assume the uncertainty of taking risk, guided the production process to assure that demands in the marketplace were satisfied. Baudeau embraced Cantillon's view of the entrepreneur as a risk-taker, but he also attributed the characteristic of being an innovator to the person who invents and applies new production 
techniques. However, it may have been Joseph Schumpeter (1883-1950) who was the most influential classical scholar by defining the entrepreneur as an innovator. Schumpeter

(1942) wrote that what distinguishes the entrepreneur from other actors in the economy is his/her willingness to pursue innovative activity. ${ }^{1}$

Classical concepts of entrepreneurship view the individual as the primary economic agent of change who alters the status quo social and economic environment. That change is predicated by innovative or creative action that may or may not result in a tangible innovation (i.e. something, like a new technology, that is put into use). The classical literature, with an emphasis on Schumpeter's early views, suggests that innovative action of an entrepreneur will result in an observable innovation; but, contemporary scholars have tempered that view by emphasizing that change per se even in the absence of an innovation is a definable output from entrepreneurship. ${ }^{2}$

\section{Literature on public-sector entrepreneurship}

The concept of public-sector entrepreneurship is of more recent vintage than the classical concepts of the entrepreneur summarized above. Perhaps the earliest mention of the concept was by Wagner (1966) and Ostrom (1964). Wagner, who made no mention of Schumpeter, conceived of what might be called direct public-sector entrepreneurship. Wagner's public-sector entrepreneur operates directly through the expenditure and service mechanisms of government, and thus he/she supplies collective benefits for political profit or gain. In contrast, Ostrom's concept was that of indirect public-sector entrepreneurship. Her public-sector entrepreneur altered the market environment in an attempt to influence indirectly desirable behaviours on the part of private-sector entrepreneurs. Ostrom's view is, in essence, about innovative action, although she did not define it using those terms.

The extant literature, including the foundational work of Ostrom and Wagner, focuses on the actions of individual public-sector entrepreneurs. Alternative definitions of who a public-sector entrepreneur is and what he/she does are presented in Table 1. As discussed below, Wagner's view of direct public-sector entrepreneurship being dominated by political gain, which could be associated with self-serving actions, dominates this literature. The authors of these definitions of the public-sector entrepreneur are also identified by their academic discipline.

There are some discipline-specific characteristics of who a public-sector entrepreneur is and what he/she does that frame this literature. Of particular note, scholars have emphasized innovativeness and alertness as the initiating forces guiding the public-sector entrepreneur as he/she pursues his/her objectives. The public-sector entrepreneur is thus a dynamic rather than static actor.

\footnotetext{
${ }^{1}$ Schumpeter (1942, p. 13) wrote: 'The function of entrepreneurs is to reform or revolutionize the pattern of production by exploiting an invention, or more generally, an untried technological possibility for producing a new commodity or producing an old one in a new way.'

${ }^{2}$ Autio et al. (2014, p. 1097) emphasize that 'innovation is not the same as entrepreneurship'. They also emphasize that innovative entrepreneurial action is an important descriptor of changes in institutional structures, a point that we revisit below.
} 
Table 1. Views of the public-sector entrepreneur, by authors (listed chronologically) and by academic disciplines

\begin{tabular}{|c|c|c|}
\hline Author(s) & The public-sector entrepreneur is the person who ... & Academic discipline \\
\hline Ostrom $(1964,2005)$ & $\begin{array}{l}\text { produces public gains through the creation of new, } \\
\text { innovative non-market organizations in changing } \\
\text { environments. }\end{array}$ & $\begin{array}{l}\text { Public } \\
\text { administration/political } \\
\text { science }\end{array}$ \\
\hline Wagner (1966) & supplies collective benefits for political gain. & Economics \\
\hline Jones (1978) & $\begin{array}{l}\text { maximizes own returns through rational allocations of } \\
\text { resources. }\end{array}$ & $\begin{array}{l}\text { Public } \\
\text { administration/political } \\
\text { science }\end{array}$ \\
\hline Casson $(1982,2003)$ & $\begin{array}{l}\text { specializes in making decisions about coordinating } \\
\text { resources. }\end{array}$ & Economics \\
\hline Kingdon (1984) & attempts to control public policy. & $\begin{array}{l}\text { Public } \\
\text { administration/political } \\
\text { science }\end{array}$ \\
\hline Ramamurti (1986) & $\begin{array}{l}\text { pursues activity to initiate, maintain, or aggrandize public- } \\
\text { sector organizations. }\end{array}$ & $\begin{array}{l}\text { Public } \\
\text { administration/political } \\
\text { science }\end{array}$ \\
\hline Oakerson and Parks (1988) & has the ability and freedom to pursue new initiatives. & $\begin{array}{l}\text { Public } \\
\text { administration/political } \\
\text { science }\end{array}$ \\
\hline Kirchheimer (1989) & $\begin{array}{l}\text { starts new organizations, produces new services, applies } \\
\text { innovative strategies, and is willing to bear risk. }\end{array}$ & $\begin{array}{l}\text { Public } \\
\text { administration/political } \\
\text { science }\end{array}$ \\
\hline Hughes (1991) & is a bureaucrat and who makes discretionary decisions. & Economics \\
\hline Bellone and Goerl (1992) & seeks new revenue sources for economic development. & $\begin{array}{l}\text { Public } \\
\text { administration/political } \\
\text { science }\end{array}$ \\
\hline Osborne and Gaebler (1992) & $\begin{array}{l}\text { uses resources in new ways to maximize productivity and } \\
\text { effectiveness. }\end{array}$ & $\begin{array}{l}\text { Public } \\
\text { administration/political } \\
\text { science }\end{array}$ \\
\hline Roberts (1992) & generates innovative ideas and brings them to fruition. & $\begin{array}{l}\text { Public } \\
\text { administration/political } \\
\text { science }\end{array}$ \\
\hline $\begin{array}{l}\text { Schneider and Teske } \\
\text { (1992); Schneider } \text { et al. (1995) }\end{array}$ & acts in the political arena for political profit. & $\begin{array}{l}\text { Public } \\
\text { administration/political } \\
\text { science }\end{array}$ \\
\hline Boyett (1997) & is able to identify and exploit market opportunities. & Management \\
\hline Moon (1999) & $\begin{array}{l}\text { enhances customer satisfaction, reduces red tape, or } \\
\text { engages in risk taking. }\end{array}$ & $\begin{array}{l}\text { Public } \\
\text { administration/political } \\
\text { science }\end{array}$ \\
\hline Morris and Jones (1999) & $\begin{array}{l}\text { creates value for citizens by combining resources to } \\
\text { exploit social opportunities. }\end{array}$ & Management \\
\hline Sadler (2000) & $\begin{array}{l}\text { identifies and exploits opportunities by being innovative in } \\
\text { an uncertain environment. }\end{array}$ & Management \\
\hline Holcombe (2002) & $\begin{array}{l}\text { observes and acts on opportunities for political profit or } \\
\text { gain. }\end{array}$ & Economics \\
\hline Zerbinati and Souitaris (2005) & discovers and exploits rewarding opportunities. & Management \\
\hline Shockley et al. (2006) & is alert to, and acts on, political opportunities. & Economics \\
\hline
\end{tabular}




\begin{tabular}{|lll|}
\hline Author(s) & The public-sector entrepreneur is the person who ... & Academic discipline \\
\hline Bernier and Hafsi (2007) & $\begin{array}{l}\text { increases the public sector's ability to deliver services of } \\
\text { value. }\end{array}$ & $\begin{array}{l}\text { Public } \\
\text { administration/political } \\
\text { science }\end{array}$ \\
$\begin{array}{l}\text { Schnellenbach (2007) } \\
\text { Klein et al. (2009, 2011) }\end{array}$ & $\begin{array}{l}\text { is a promoter of new political paradigms. } \\
\text { experiments with resource combinations to achieve social } \\
\text { objectives. } \\
\text { takes innovative actions in the face of risk and } \\
\text { uncertainty. }\end{array}$ & $\begin{array}{l}\text { Management } \\
\text { is a civil servant who uses resources in an innovative } \\
\text { manner to create social value. } \\
\text { is competitive, enterprising, customer driven, anticipatory, }\end{array}$ \\
$\begin{array}{l}\text { Zampetakis and Moustakis } \\
\text { market oriented, and catalytic. } \\
\text { Padt and Luloff (2011) }\end{array}$ & $\begin{array}{l}\text { Management } \\
\text { initiates change by adapting, innovating, and assuming } \\
\text { risk for the benefit of society. }\end{array}$ & Management \\
\hline
\end{tabular}

Source: Based on Leyden and Link (2015).

Among the scholars from economics, Casson (2003), Holcombe (2002), Shockley et al. (2006), and Schnellenbach (2007) emphasize that the public-sector entrepreneur's behaviour is consistent with the neoclassical economics assumption of utility maximization. These writers talked about maximization in terms of utility being synonymous with political profit. Hughes (1991) and Link and Link (2009) are the exceptions from the economics literature; their publicsector entrepreneur focuses on bureaucratic and institutional missions, innovative activity, and, consequentially, economic growth.

With the exception of Casson, the characterization of the public-sector entrepreneur by each of the above authors contains Schumpeterian elements, meaning that the actions of the public-sector entrepreneur are an innovative means towards an end. But few of the authors recognize either the distinction between ordinary risks and the risks associated with uncertainty or suggest that the willingness to accept the risks associated with uncertainty is fundamentally part of the publicsector entrepreneur's character or demeanour.

Building on the general theme of innovativeness and alertness as characteristics of how the public-sector entrepreneur begins to pursue his/her objectives, most of the authors have characterized the entrepreneur's actions as being direct, in the Wagner sense, rather than indirect, in the Ostrom sense, in the manner through which their objectives are pursued. As with the treatment of risk and uncertainty, there are again a few notable exceptions. For example, among the scholars in economics, Link and Link (2009) make an argument in favour of public-sector entrepreneurs altering the private-sector market environment by transferring risk and uncertainty to the public sector thereby inducing private-sector innovative behaviour. Among the scholars in public administration/political science, Bellone and Goerl (1992) argue that public-sector entrepreneurs act indirectly by providing incentives to induce private-sector actors to act in a manner that brings about the public-sector entrepreneur's desired objectives.

The various descriptions of public-sector entrepreneurship in Table 1 can be summarized not only in terms of the discipline of the authors but also in terms of alternative motives for entrepreneurial actions. For example, the management literature, first referenced in 1997, can be 
thought about in terms of whether the public-sector entrepreneur is motivated by the goal of increasing personal gain (e.g. Morris and Jones, 1999; Sadler, 2000; Zerbinati and Souitaris, 2005; Klein et al., 2009, 2011; Hisrich and Al-Dabbagh, 2012) or by the goal of increasing social value by fulfilling an organizational mission (e.g. Boyett, 1997; Zampetakis and Moustakis, 2010; Padt and Luloff, 2011). The exploitation of opportunities is a common underpinning for the actions of the public-sector entrepreneur in the views of most scholars who have contributed to the management literature.

Within the public administration/political science literature, there is less of a convergence of views about motives than there has been in the management literature. For example, Jones (1978), Ramamurti (1986), Schneider and Teske (1992), and Schneider et al. (1995), suggest that the public-sector entrepreneur is, as Wagner (1966) had initially argued, interested solely in personal aggrandizement through the manipulation of the political or the institutional apparatus of government. Oakerson and Parks (1988), Bellone and Goerl (1992), Osborne and Gaebler (1992), Moon (1999), and Bernier and Hafsi (2007) suggest that the public-sector entrepreneur is focused on fulfilling the mission of his/her own public organization through improved efficiency in response to social needs.

To complement Table 1, Table 2 alternatively characterizes the literature on public-sector entrepreneurship in terms of the differing motives of the entrepreneur. The table offers a framework for considering alternative views about the public-sector entrepreneur. The literature from Table 1 is characterized within Table 2 not only in terms of alternative motivations (i.e. opportunity recognition) for public-sector entrepreneurial action, but also in terms of the focus or intended outcomes of that recognition and action. We have divided motivations into three groups: economic gain, personal gain, and political gain for the public-sector entrepreneur.

Table 2. An alternative framework for characterizing the public-sector entrepreneurship literature

\begin{tabular}{|c|c|c|c|c|}
\hline \multirow[b]{2}{*}{ Motivations } & \multicolumn{4}{|l|}{ Intended outcomes } \\
\hline & Individual outcomes & Organizational outcomes & Policy outcomes & Social outcomes \\
\hline Economic gain & & $\begin{array}{l}\text { Kirchheimer, } * * * \\
\text { Moon*** }\end{array}$ & Link and Link* & $\begin{array}{l}\text { Oakerson and Parks, } * * * \\
\text { Bellone and Goerl,*** } \\
\text { Boyett, } * * \\
\text { Sadler, } * * \\
\text { Zerbinati and Souitaris** }\end{array}$ \\
\hline Personal gain & $\begin{array}{l}\text { Jones, } * * * \\
\text { Roberts*** }\end{array}$ & $\begin{array}{l}\text { Ramamurti,*** } \\
\text { Schnellenbach,* } \\
\text { Hisrich and Al-Dabbagh** }\end{array}$ & Kingdom*** & $\begin{array}{l}\text { Ostrom, }{ }^{* * *} \\
\text { Casson, }{ }^{*} \\
\text { Morris and Jones, }{ }^{* *} \\
\text { Klein } \text { et al., }{ }^{* *} \\
\text { Padt and Luloff** }\end{array}$ \\
\hline Political gain & Shockley et al.* & $\begin{array}{l}\text { Wagner, } \\
\text { Hughes, } \\
\text { Schneider et al., } \\
\text { Bernier and Hafsi*** }\end{array}$ & Holcombe* & $\begin{array}{l}\text { Osborne and Gaebler, }{ }^{* * *} \\
\text { Zampetakis and Moustakis** }\end{array}$ \\
\hline
\end{tabular}

Notes: The academic disciplines of the authors are denoted by $*$ for economics, $* *$ for management, $* * *$ for public administration/political science.

We have also divided the intended outcomes of the public-sector entrepreneur's actions/initiatives into four groups: individual outcomes, organizational outcomes (i.e. of a 
political group or agency), policy outcomes, and social outcomes. There is uncertainty associated with each of these outcomes; that is, there is uncertainty about the extent to which the publicsector entrepreneur's action, regardless of his/her motivations, will achieve his/her desired outcomes. We have placed the authors discussed in Table 1 in what we view as the single most appropriate cell in Table 2. We also carry over from Table 1 each author's academic discipline.

We have aligned the majority of the scholars from Table 1 with their conceptual public-sector entrepreneur pursuing social outcomes as well as organizational outcomes. And, there appear to be alternative motivations for pursuing these intended outcomes. Even those writers who characterize the motivations of the public-sector entrepreneur as being political gain attribute the entrepreneur's intended outcomes as being socially based or organizationally based.

As an aside, the concept of public-sector entrepreneurship might be an antecedent to the notion of public-sector innovation, although the writers on public-sector innovation do not attribute their discourse to entrepreneurial actions. ${ }^{3}$ Public-sector innovation is a concept written about to a greater degree by European scholars than US scholars. According to OECD (2017, p. 11), for example: 'Public sector innovation is about finding new and better means to achieve public ends.' And, innovation in the public sector has three defining characteristics (OECD, 2015, p. 14): 'novelty, implementation, and impact'. We note the concept of public-sector innovation here, but we do not expand on it in this paper. We note the concept because, in a broad sense, there might be an overlap of ideas between those scholars who emphasize organizational outcomes as an intended consequence of the actions of the public-sector entrepreneur and those scholars whose starting point is the outcome of public-sector innovation without any reference to the initiating forces. For example, Clark et al. (2008) argue that the drivers of public-sector innovation are political push, pressure for economy and improved efficiency, and pressure for improved service quality; however, they do not identify the sources for political push or pressure.

In our view, public-sector entrepreneurship is a variant of the classical notion of entrepreneurship. What distinguishes public-sector entrepreneurship is the institutional environment in which entrepreneurial action occurs. Public-sector and private-sector entrepreneurs identify (i.e. are perceptive of) heretofore unexploited opportunities and then exploit them (i.e. take innovative action); the outcome of an entrepreneur's perception and innovative action is of course uncertain. Following the literature, public-sector and private-sector entrepreneurs have differing motivations for their actions, some more altruistic than others; and, the attendant processes focus on alternative outcomes, some narrow in scope (organizational outcomes) and some broad in scope (social outcomes).

We broaden the individual-level conceptualizations, recognizing that public-sector entrepreneurship behaviour can occur at organization and policy levels. Further, public-sector entrepreneurship can generate both social and economic outcomes. While such a focus does not preclude other types of benefits (i.e. organizational), we see these as ancillary to the primary purpose of public-sector entrepreneurship. Thus, we offer a synthesis definition of public-sector entrepreneurship: Public-sector entrepreneurship refers to the formation of innovative public-

\footnotetext{
${ }^{3}$ For a valuable discussion of the evolution of the concept of public-sector innovation, see León et al. (2012). For a review of the academic literature on public-sector innovation, see De Vries et al. (2016).
} 
sector initiatives that transform a status quo social and economic environment into one that is more conducive to creative change in the face of uncertainty.

Table 3. Public-sector entrepreneurial initiatives

\begin{tabular}{|c|c|c|c|c|c|c|}
\hline $\begin{array}{l}\text { Public-sector } \\
\text { initiative }\end{array}$ & $\begin{array}{l}\text { Initiating } \\
\text { party }\end{array}$ & $\begin{array}{l}\text { Targeted } \\
\text { party }\end{array}$ & $\begin{array}{l}\text { Direct versus } \\
\text { indirect nature } \\
\text { of the initiative }\end{array}$ & $\begin{array}{l}\text { Innovative nature } \\
\text { of the initiative }\end{array}$ & $\begin{array}{l}\text { Status } \\
\text { quo economic } \\
\text { environment } \\
\text { transformed }\end{array}$ & $\begin{array}{l}\text { Dimensions of } \\
\text { uncertainty }\end{array}$ \\
\hline $\begin{array}{l}\text { Saving Brains } \\
\text { Grand } \\
\text { Challenge } \\
\text { Program }\end{array}$ & $\begin{array}{l}\text { Canadian } \\
\text { government }\end{array}$ & $\begin{array}{l}\text { Children in } \\
\text { need of } \\
\text { humanitarian } \\
\text { assistance }\end{array}$ & $\begin{array}{l}\text { Direct funding but } \\
\text { achieves GCC } \\
\text { goals indirectly }\end{array}$ & $\begin{array}{l}\text { The perception } \\
\text { and action on } \\
\text { humanitarian } \\
\text { issues by those } \\
\text { capable of funding } \\
\text { the challenge is } \\
\text { new }\end{array}$ & $\begin{array}{l}\text { Improving the } \\
\text { health and } \\
\text { wellbeing of } \\
\text { those in need of } \\
\text { humanitarian } \\
\text { assistance }\end{array}$ & $\begin{array}{l}\text { Humanitarian } \\
\text { effort can have } \\
\text { uncertain } \\
\text { consequences if } \\
\text { not successful or } \\
\text { if short lived }\end{array}$ \\
\hline $\begin{array}{l}\text { Government } \\
\text { Performance } \\
\text { and Results } \\
\text { Act }\end{array}$ & $\begin{array}{l}\text { US } \\
\text { Congress }\end{array}$ & $\begin{array}{l}\text { Federal } \\
\text { agencies }\end{array}$ & $\begin{array}{l}\text { Direct charge to } \\
\text { agency managers }\end{array}$ & $\begin{array}{l}\text { Charging } \\
\text { programme } \\
\text { managers to be } \\
\text { publicly } \\
\text { accountable is } \\
\text { innovative }\end{array}$ & $\begin{array}{l}\text { Public managers } \\
\text { who had not } \\
\text { previously been } \\
\text { accountable for } \\
\text { their actions }\end{array}$ & $\begin{array}{l}\text { The precision of } \\
\text { public evaluation } \\
\text { studies is } \\
\text { uncertain as is the } \\
\text { interpretative } \\
\text { ability of public } \\
\text { officials }\end{array}$ \\
\hline $\begin{array}{l}\text { Bayh-Dole Act } \\
\text { and Stevenson- } \\
\text { Wydler } \\
\text { Technology } \\
\text { Innovation Act }\end{array}$ & $\begin{array}{l}\text { US } \\
\text { Congress }\end{array}$ & $\begin{array}{l}\text { Universities } \\
\text { and private- } \\
\text { sector firms; } \\
\text { Federal } \\
\text { laboratories }\end{array}$ & $\begin{array}{l}\text { Indirect option to } \\
\text { universities and a } \\
\text { direct charge to } \\
\text { Federal } \\
\text { laboratories; } \\
\text { effects are } \\
\text { indirect based on } \\
\text { research success }\end{array}$ & $\begin{array}{l}\text { Transferring } \\
\text { technology from } \\
\text { both universities } \\
\text { and Federal } \\
\text { laboratories } \\
\text { creates new } \\
\text { production } \\
\text { possibilities for } \\
\text { firms }\end{array}$ & $\begin{array}{l}\text { Advancement of } \\
\text { knowledge within } \\
\text { firms, which } \\
\text { enhances } \\
\text { economic } \\
\text { growth. }\end{array}$ & $\begin{array}{l}\text { Adopting } \\
\text { technology from } \\
\text { universities is } \\
\text { outside of the } \\
\text { routine and thus } \\
\text { has uncertain } \\
\text { outcomes }\end{array}$ \\
\hline $\begin{array}{l}\text { Small Business } \\
\text { Innovation } \\
\text { Research } \\
\text { (SBIR) } \\
\text { programme }\end{array}$ & $\begin{array}{l}\text { US } \\
\text { Congress }\end{array}$ & $\begin{array}{l}\text { Small firms }(< \\
500 \\
\text { employees) }\end{array}$ & $\begin{array}{l}\text { Direct charge to } \\
\text { specific agencies } \\
\text { but effects are } \\
\text { indirect based on } \\
\text { research success }\end{array}$ & $\begin{array}{l}\text { Using small firms } \\
\text { to do R\&D to } \\
\text { meet agency needs } \\
\text { had not previously } \\
\text { been used }\end{array}$ & $\begin{array}{l}\text { Increasing less } \\
\text { than socially } \\
\text { desirable levels of } \\
\text { R\&D activity in } \\
\text { small firms }\end{array}$ & $\begin{array}{l}\text { Uncertainty is a } \\
\text { characteristic of } \\
\text { any R\&D efforts, } \\
\text { especially in small } \\
\text { firms }\end{array}$ \\
\hline
\end{tabular}

It is important to point out that the above literature on public-sector entrepreneurship generally fails to offer any detailed examples of such initiatives. The literature is, for the most part, conceptual, but perhaps that is how a body of foundational or theoretical literature should be. To anticipate the remainder of this paper, having reviewed the literature on public-sector entrepreneurship, we offer in the following section specific initiative examples. Whereas most of the literature on public-sector entrepreneurship has followed Wagner's (1966) view of direct actions by the public-sector entrepreneur by focusing on his/her motives, the public-sector initiatives discussed below also reflect elements of Ostrom's (1964) view of indirect actions by the public-sector entrepreneur. We summarize these examples of public-sector entrepreneurship initiatives in Table 3. For example, in all cases, the initiating party is a public-sector organization or individual within that organization. The targeted parties are actors in both the public and the private sectors. The initiatives differ in terms of the initiating party acting directly or indirectly. The final three columns in Table 3 indicate the innovative nature of the initiative, the social and economic environment being transformed, and the dimension of uncertainty associated with the 
initiative. These initiatives are discussed individually in section IV. We note, too, when the initiatives have been emulated in other countries.

\section{Examples of public-sector entrepreneurship}

In this section, we describe Table 3's examples of public-sector entrepreneurial initiatives.

\section{(i) Saving Brains Grand Challenge Program of 2011}

Hayter (2015a) defines grand challenges as trans-regional, trans-national problems for which no single organization, sector, or country has the financial or scientific resources to address on its own. Grand Challenges Canada (GCC) was established by the Canadian government in 2010 as 'a non-profit organization created to identify global Grand Challenges, fund researchers and organizations to address them, and support the implementation and commercialization of the solutions that emerge'. ${ }^{4}$ It was initially funded at Can $\$ 225 \mathrm{~m} .{ }^{5}$

GCC is an example of transforming a status quo social and economic environment into one that is more conducive to creative ways to address humanitarian needs, while recognizing opportunities to leverage private-sector forces to scale and sustain initiatives. The challenges faced by GCC are that its programmes have uncertain results, as we discuss below with respect to the Savings Brains programme.

Critical to the establishment of GCC was the assumption that grand challenge responses must be solution oriented, multi-organizational, emphasize scale, and use an innovative approach (Hayter and Link, 2018). The multi-organizational structure of GCC is particularly important. Whereas traditional humanitarian approaches emphasize dyadic relationships between donors and grant recipients, GCC provides the funding and administrative infrastructure for the concurrent participation of multiple donors from all sectors. Thus, the organizational structure of GCC is innovative in itself given the nature of the projects considered.

GCC expects its grant recipients to follow what is termed an integrated innovation approach, meaning the coordinated application of scientific and technological, social, and business innovations to develop solutions to complex challenges. The programme's emphasis on integrated innovations assumes that scientifically and technically sound health solutions have a greater chance of achieving scale and sustainability if they are developed with social and economic goals in mind. Financial sustainability is particularly important to address barriers to affordability and sustainability.

Potential grantees submit proposals to address problems in specific programme areas within GCC. Following the aforementioned integrated innovation approach, proposals must not only be technically sound; they must also lay out the potential social impact of their solution and describe the sustainability of the project including a description of the project execution plan, leadership team, and metrics for success.

\footnotetext{
${ }^{4}$ See https://gcgh.grandchallenges.org/announcement/grand-challenges-canada-launched

${ }^{5}$ In addition to participation from the Canadian government, early partnerships included the Bill and Melinda Gates Foundation and the governments of the United States, the United Kingdom, Norway, and Korea.
} 
The Saving Brains initiative at GCC illustrates a specific grand challenge effort. Saving Brains was established in 2011 after GCC identified brain development as an area of critical need especially in developing nations. According to GCC, as many as $200 \mathrm{~m}$ children, most of whom live in poverty, have a high likelihood of encountering adversity that disrupts brain development. Not only is this situation a 'devastating [potential] waste of human capital', ${ }^{6}$ but in general it means that individuals have little additional chance of working to help solve problems in their community that reinforce poverty. Saving Brains is particularly interested in developing solutions that target children affected during humanitarian crises, help adolescent parents, and demonstrate promising results but have yet to be scaled. ${ }^{7}$

While there are to date some measurable social outcomes associated with the Saving Brains public-sector initiative, the extent of achievable social and economic outcomes was uncertain when this forward-looking programme began.

(ii) Government Performance and Results Act of 1993

The 103rd Congress of the United States stated in the Government Performance and Results Act of 1993 (GPRA) that:

1. Waste and inefficiency in Federal programmes undermine the confidence of the American people in the Government and reduce the Federal Government's ability to address adequately vital public needs;

2. Federal managers are seriously disadvantaged in their efforts to improve programme efficiency and effectiveness, because of insufficient articulation of programme goals and inadequate information on programme performance; and

3. Congressional policymaking, spending decisions and programme oversight are seriously handicapped by insufficient attention to programme performance and results.

The innovative aspect of GPRA was that it sought to improve 'Federal program effectiveness and public accountability by promoting a new focus on results, service quality, and customer satisfaction' through the systematic collection and analysis of information. The uncertain aspect of GPRA was whether public-sector managers could effectively implement evaluation methods, and then use the evaluation findings to allocate their resources more efficiently.

GPRA was at the time of its passage (President's 2004 Budget, 2003, pp. 48-9):

the most significant advance in bringing accountability to government programs. ... Unfortunately, the implementation of this law has fallen short of its authors' hopes. Agency plans are plagued by performance measures that are meaningless, vague, too numerous, and often compiled by people who have no direct connection with budget decisions.

\footnotetext{
${ }^{6} \mathrm{See}, \mathrm{http} / / / \mathrm{www} . g r a n d c h a l l e n g e s . c a / p r o g r a m s /$ saving-brains/

${ }^{7}$ See, http://www.grandchallenges.ca/wp-content/uploads/2017/07/20170728-SB-R6-RFP-EN.pdf
} 
There has not yet been a systematic assessment of the effectiveness of GPRA. However, based on its intent of 'bringing accountability to government programs', this initiative, motivated by political gains, could result in social outcomes in terms of programmatic and policy efficacy and economic outcomes in terms of greater efficiency.

(iii) Bayh-Dole Act of 1980 and Stevenson-Wydler Technology Innovation Act of 1980

In December 1980, President Jimmy Carter signed into law the University and Small Business Patent Procedure Act. This Act amended Title 35 of the United States Code, entitled 'Patents'. It is this amendment that is commonly known as the Bayh-Dole Act of 1980.

According to the Act of $1980(\S 200)$, with emphasis added in italics:

It is the policy and objective of the Congress to use the patent system to promote the utilization of inventions arising from Federally supported research or development; to encourage maximum participation of small business firms in Federally supported research and development efforts; to promote collaboration between commercial concerns and nonprofit organizations, including universities; to ensure that inventions made by nonprofit organizations and small business firms are used in a manner to promote free competition and enterprise; to promote the commercialization and public availability of inventions made in the United States by United States industry and labor; to ensure that the Government obtains sufficient rights in Federally supported inventions to meet the needs of the Government and protect the public against nonuse or unreasonable use of inventions; and to minimize the costs of administering policies in this area.

The innovative nature of the Bayh-Dole Act follows from Schumpeter's (1942) definition of innovative entrepreneurial behaviour. The purposeful transfer of university-based technology was a new concept for changing the status quo social and economic environment and thus generating growth. It represents an untried possibility for a private-sector firm for producing a new commodity or an old one in a new way. It is thus a policy that is characterized by creativity. Finally, the use of any untried production process by a private-sector firm will be characterized by uncertainty.

The Bayh-Dole Act offered several provisions in support of its legislative goals. The Act aligned intellectual property policy among all Federal R\&D funding agencies, creating administrative efficiencies. It also created incentives for universities to become engaged in the technology transfer process by giving universities primary responsibility for managing technologies stemming from Federally funded research, including the ability to claim intellectual property (IP) ownership through patents (Mowery et al., 2004; Sampat, 2006).

The Bayh-Dole Act accelerated the establishment of university technology offices which devoted increasing attention to patenting and licensing university technologies as well as disclosure and reporting requirements for university employees and students (Grimaldi et al., 2011; Bradley et al., 2013a). For a small percentage of research universities, patenting and licensing activities have generated substantial revenues, which are typically reinvested in university research (Siegel et al., 2004). 
The Bayh-Dole Act is also credited with helping to spur interest among universities in academic entrepreneurship and the establishment of new university spinoff companies based on IP derived from faculty and student research (Shane, 2004; Hayter, 2016a, $b$; Hayter et al., 2017). Further, universities and regional governments have established spinoff support programmes, such as early-stage venture funds (Croce et al., 2014), university research parks (Link and Scott, 2007), and proof of concept centres (Bradley et al., 2013b) to encourage and support technology commercialization. ${ }^{8}$

Congress also passed the Stevenson-Wydler Technology Innovation Act in 1980. As stated in the Act:

Technology and industrial innovation are central to the economic, environmental, and social well-being of citizens of the United States. ... Many new discoveries and advances in science occur in universities and Federal laboratories, while the application of this new knowledge to commercial and useful public purposes depends largely upon actions by business and labor... . No comprehensive national policy exists to enhance technological innovation for commercial and public purposes. There is a need for such a policy, including a strong national policy supporting domestic technology transfer and utilization of the science and technology resources of the Federal Government. . . The Federal laboratories and other performers of Federally funded research and development frequently provide scientific and technological developments [and these] developments should be made accessible. .. . There is a need to provide means of access and to give adequate personnel and funding support to these means.

Prior to the Stevenson-Wydler Technology Innovation Act, technology transfer was not an explicit mission of Federal laboratories. The Act makes clear that it is now the responsibility of each Federal laboratory to establish an office as well as mechanisms to transfer its technology to those organizations that will benefit.

The motivation behind the Bayh-Dole Act and the Stevenson-Wydler Technology Innovation Act was to reverse the present productivity slowdown in domestic industries; however, a portion of the research to date suggests that this political motivation was successful and resulted in measurable social and economic outcomes and subsequent increases in productivity growth (Grimaldi et al., 2011; Link et al., 2011; Bozeman and Link, 2015).

(iv) Small Business Innovation Research (SBIR) programme

The objectives of the Small Business Innovation Development Act of 1982 are:

\footnotetext{
${ }^{8}$ The Bayh-Dole Act also served as a legislative example for other countries interested in technology transfer. A number of other countries have in fact adopted policies similar to the Act. The Association for University Technology Managers (AUTM) reports, without any detailed information, that Brazil, China, Denmark, Finland, Germany, Italy, Japan, Malaysia, Norway, Philippines, Russia, Singapore, South Africa, South Korea, and the United Kingdom have all adopted similar legislation. Some specifics about selected countries' policies are available in BayhDole25 (2006) and So et al. (2008). See, https://www.autm.net/advocacy-topics/governmentissues/advocacy-public-policy/legislative-issues/Bayh-dole-act/
} 
(i) to stimulate technological innovation;

(ii) to use small business to meet Federal research and development needs;

(iii) to foster and encourage participation by minority and disadvantaged persons in technological innovation; ${ }^{9}$ and

(iv) to increase private-sector commercialization of innovations derived from Federal research and development.

The Act required all US agencies with an extramural research budget of $\$ 100 \mathrm{~m}$ or more to set aside 0.2 per cent of their 1982 budget to support a small business innovation research programme that meets the requirements of the Act. Over time, the set-aside percentage has increased to its current level of 3.2 per cent of the 2017 extramural research budget.

With the funding mandated by the 1982 Act, Small Business Innovation Research (SBIR) programme awards were created with three designed phases of outlays. Phase I awards generally do not now exceed $\$ 150,000$ over 6 months. The purpose of these awards is to determine the 'scientific and technical merit and feasibility of ideas'. Phase II awards are now capped at $\$ 1 \mathrm{~m}$ over 2 years. These awards are for the business to develop further its proposed research, ideally leading to a commercializable product, process, or service. Further work on the projects occurs in Phase III, which does not involve SBIR funding. During this stage, firms are expected to raise additional financing to ensure that their product, process, or service can move into the marketplace.

The SBIR programme is innovative not only in terms of its focus on small firms - a new emphasis for US policy — but also for its emphasis on their R\&D investments. Particularly noteworthy is the programme's charge to combine Federal mission agency research needs and other social objectives with the goal of spurring innovation among small firms. Thus, the SBIR programme represented a vehicle for producing technologies in a new way.

With any policy that funds R\&D projects, especially in small firms, there will be an element of uncertainty about the output of the project. In fact, only about one-half of Phase II projects commercialize their R\&D projects although commercialization is an objective of the programme (Link and Scott, 2010). And, the SBIR programme altered the status quo social and economic environment and thus promoted growth. ${ }^{10}$ Not only does the programme expand the R\&D potential of small firms, but it also affords such firms experience in opportunity recognition, an important characteristic of an entrepreneur.

\footnotetext{
${ }^{9}$ When the Act was reauthorized in 1992, this third objective was changed to focus also on women: 'to provide for enhanced outreach efforts to increase the participation of . . small businesses that are 51 per cent owned and controlled by women.'

${ }^{10}$ According to Wessner (2008, pp. 52-3): '[G]overnments around the world are increasingly adopting SBIR type programs to encourage the creation and growth of innovative firms in their economies. Sweden and Russia have adopted SBIR-type programs. The United Kingdom's SIRI program is similar in concept. The Netherlands has a pilot SBIR program underway and is looking to expand its scope. Asia, Japan, Korea, and Taiwan have also adopted the SBIR concept with varying degrees of success, as a part of their national innovation strategies. This level of emulation across national innovation systems is striking and speaks to the common challenges addressed by SBIR awards and contracts.'
} 
Interestingly, the SBIR programme has also captured the attention of state policy-makers. Several states have created outreach and matching grant programmes specifically designed to improve the chances of obtaining SBIR awards and to amplify their impact, respectively (Lanahan and Feldman, 2015). According to these authors, state SBIR programmes not only emerged from Federal action, but they were also a result of the internal political and economic factors from the states instituting new state SBIR programmes as well as influence from peer states.

While the programme has received much acclaim, policy-makers remain concerned that some agency SBIR programmes allow small companies to become so-called 'SBIR mills', or companies principally funded through multiple SBIR awards and that do not have separate businesses or commercial objectives (Wessner, 2008). While these concerns have been largely dismissed (e.g. NRC, 2016), scholars have recently found that some academic entrepreneurs establish spinoff companies to obtain SBIR awards to support their academic research agenda, not necessarily with intentions of commercializing their technology (Hayter, 2011, 2015b).

As reviewed by Link and Scott $(2010,2012)$, the literature related to the SBIR programme suggests that it has resulted in social outcomes in the sense of increasing technology development and attendant employment growth.

\section{Concluding remarks}

We defined public-sector entrepreneurship as having three distinct components: actions that are innovative, that transform a status quo economic environment, and that are characterized by uncertainty. While the literature on public-sector entrepreneurship dates to the mid-1960s, the elements that define it can be traced as far back as the early writing of the classical economists who first defined who an entrepreneur is and what he/she does. These classical writers provided the foundation for the modern study of private-sector entrepreneurship; however, these classical writers ignored the possible role of public-sector entrepreneurs acting in a manner similar to that of private-sector entrepreneurs.

The literature on public-sector entrepreneurship is an extension of classical thought on dynamic entrepreneurship. The public-sector literature is focused on how the public-sector entrepreneur's actions and/or initiatives transform a status quo social and economic environment. Such actions and/or initiatives illustrate the dynamic nature of public-sector entrepreneurship. In this paper, we offer examples of public-sector entrepreneurial initiatives that resulted in policy actions that changed or are changing the status quo social and economic environment. At the time these initiatives were promulgated, their outcomes were uncertain, although the policy literature suggests that each has resulted in both social and economic outcomes.

What differentiates public-sector entrepreneurship from private-sector entrepreneurship is the context in which it occurs. Public organizations are often governed by rules and processes that purposely limit entrepreneurial action under the presumption that aggrandizement and corruption damage the public weal. Further, public-sector entrepreneurship might be motivated to some extent by economic gains but to a larger extent by personal or political gains. Still, the outcomes from these actions could result in positive social and economic outcomes. 
When one focuses on the implications of the dynamic nature of public-sector entrepreneurship, one is de facto identifying the need to evaluate such actions with thought and evidence about the consequences of transforming a status quo social and economic environment. Yet, democratic rules and processes, however well intended, make the design, implementation, and evaluation of dynamic policies difficult at best. At times, periodic authorization and accompanying evaluation can be designed into acts of public-sector entrepreneurship, such as the need to reauthorize the SBIR programme every 8 years. Or, legislation can be permanent, implying that interpretations may always be left to others beyond the public-sector entrepreneurs themselves. In short, dynamism within the context of public-sector entrepreneurship may be a function of the design of the innovative action itself as well as its interaction with environmental factors.

Our examples of initiatives show that public-sector entrepreneurship is a multi-level phenomenon. Governmental or congressional legislation is particularly important within representative democracies, yet our examples illustrate opportunity recognition and corresponding entrepreneurial action among many actors in the public sectors. Using the SBIR programme as one example, states recognized the opportunity to improve the likelihood that local small business might win awards and, once they do, leverage the impact of their funded project through matching programmes. Similarly, the Bayh-Dole Act accelerated the development and diffusion of organizational innovations within universities, including technology transfer offices and internal university entrepreneurship support programmes.

Future public-sector entrepreneurship research might focus on the role of other branches of government and explore the extent to which entrepreneurial actions spill over to innovative actions among other public-sector actors. Further, the concept of public-sector entrepreneurship might be expanded to include the innovative action of non-governmental organizations and industry which, though they may have different purposes, nonetheless seek to fulfil public missions. Scholars might also examine public entrepreneurship among sectors: to what extent do multiple organizations recognize opportunities and undertake entrepreneurial action collectively to generate social and economic benefits?

Future public-sector entrepreneurship research might also focus on research aimed at developing more public-sector entrepreneurs or providing incentives for more public-sector actors to act in an entrepreneurial manner. This raises the question of how to develop or incentivize individuals in the public sector to perceive opportunities and to develop means to act on them. Perhaps one policy initiative that might accomplish this objective is to use publicly funded inducement prizes as a motivating force.

Publicly funded prizes to accomplish public objectives is not a new concept. Stine (2009) notes that public-sector prizes have been used at least since the eighteenth century to incentivize private-sector individuals and groups to be innovative. Although the examination by Khan (2015) of the long historical record about prizes does not support the idealized view of their effectiveness as inducements for innovation, perhaps scholarship and experience with prize competitions to promote public-sector entrepreneurship can improve on the historical record of performance, and then an appropriately revised approach could be used to incentivize publicsector individuals and groups. The Obama administration began an initiative to have public 
agencies use prizes to incentivize the private sector to provide innovative ideas improving the performance of the public agencies, in the sense of advancing their core missions, when

[o]n January 4, 2011, President Obama signed into the law the America COMPETES Reauthorization Act of 2010 (COMPETES). Section 105 of COMPETES added Section 24 (Prize Competitions) to the Stevenson-Wydler Technology Innovation Act of 1980, granting all agencies broad authority to conduct prize competitions to spur innovation, solve tough problems, and advance their core missions. (Office of Science and Technology Policy, 2014, p. 5).

Our suggestion is that public-sector individuals and groups be participants in the innovationinducing prize competitions.

Whereas the reward to the private-sector winner is typically financial, the reward to the publicsector individuals could range from recognition or publicity to cash prizes. A fundamental premise in economics is that economic actors respond to incentives; both consumers as well as producers respond to prices. This same concept should be researched to see if it will lead to policies to incentivize greater public-sector entrepreneurial activity; study of the prize competitions initiated under the authority of Section 105 of the America COMPETES Reauthorization Act of 2010 would provide a useful beginning.

Finally, future scholarship might examine how public-sector entrepreneurship differs by specific policy area and sectoral actor. For example, how might the establishment and evolution of charter schools demonstrate both policy-level entrepreneurial thinking within the public sector and individual or organizational charter school initiatives among non-profit organizations in response to the opportunity to meet the educational needs of impacted communities? How might different entrepreneurial responses lead to different social and economic outcomes?

Past conceptual research on public-sector entrepreneurship will be the prologue to future applied research that defines, through examples, actions that change the status quo social and economic environment into one that is more conducive to creative change in the face of uncertainty.

This paper has benefitted from the comments and suggestions of Professor Donald Siegel, who discussed our paper at the developmental workshop for this special issue, and from an anonymous referee.

\section{References}

Autio, E., Kenney, M., Mustar, P., Siegel, D., and Wright, M. (2014), 'Entrepreneurial Innovation: The Importance of Context', Research Policy, 43, 1097-108.

Baudeau, N. (1910), Premiere Introduction a la Philosophie Economique, edited by A. Dubois. Paris, P. Geuthner, originally published in 1767.

BayhDole25 (2006), The Bayh-Dole Act at 25, New York, BayhDole25, Inc.

Bellone, C. J., and Goerl, G. F. (1992), 'Reconciling Public Entrepreneurship and Democracy', Public Administration Review, 52, 130-4. 
Bernier, L., and Hafsi, T. (2007), 'The Changing Nature of Public Entrepreneurship', Public Administration Review, 67, 488-503.

Boyett, I. (1997), 'The Public Sector Entrepreneur-A Definition', International Journal of Entrepreneurial Behaviour and Research, 3, 77-92.

Bozeman, B., and Link, A. N. (2015), 'Toward an Assessment of Impacts from US Technology and Innovation Policies', Science and Public Policy, 43, 369-76.

Bradley, S. R., Hayter, C. S., and Link, A. N. (2013a), 'Models and Methods of University Technology Transfer', Foundations and Trends in Entrepreneurship, 9, 365-570.

$(2013 b)$, 'Proof of Concept Centers in the United States: An Exploratory Look', Journal of Technology Transfer, 38, 349-81.

Cantillon, R. (1931), Essai sur la Nature du Commerce en General, edited and translated by H. Higgs, London, Macmillan.

Casson, M. (1982), The Entrepreneur: An Economic Theory, Oxford, Martin Robinson. (2003), The Entrepreneur: An Economic Theory, 2nd edn, Cheltenham, Edward Elgar.

Clark, J., Good, B., and Simmonds, P. (2008), 'Innovation in the Public and Third Sectors', NESTA Working Paper, London.

Croce, A., Grilli, L., and Murtinu, S. (2014), 'Venture Capital Enters Academia: An Analysis of University-managed Funds', Journal of Technology Transfer, 39, 688-715.

De Vries, H., Bekkers, V., and Tummers, L. (2016). 'Innovation in the Public Sector: A Systematic Review and Future Research Agenda', Public Administration, 94, 146-66.

Grimaldi, R., Kenney, M., Siegel, D., and Wright, M. (2011), '30 Years after Bayh-Dole: Reassessing Academic Entrepreneurship', Research Policy, 40, 1045-57.

Hayter, C. S. (2011), 'In Search of the Profit-maximizing Actor: Motivations and Definitions of Success from Nascent Academic Entrepreneurs', Journal of Technology Transfer, 36, 340-52.

(2015a), 'Grand Challenge Model of R\&D', in D. B. Audretsch, A. N. Link, and M. L. Walshok (eds), Oxford Handbook of Local Competitiveness, New York, Oxford University Press, 237-54.

(2015b), 'Public or Private Entrepreneurship? Revisiting Motivations and Definitions of Success among Academic Entrepreneurs', Journal of Technology Transfer, 40, 1003-15.

(2016a), 'Constraining Entrepreneurial Development: A Knowledge-based View of Social Networks among Academic Entrepreneurs', Research Policy, 45, 475-90.

(2016b), 'A Trajectory of Early-stage Spinoff Success: The Role of Knowledge Intermediaries within an Entrepreneurial University Ecosystem', Small Business Economics, 47, 633-56.

Link, A. N. (2018), 'Broadening the Scope of Public Sector Entrepreneurship: Lessons Learned from Grand Challenge Programs', Working Paper, Arizona State University. 
Lubynsky, R., and Maroulis, S. (2017), 'Who Is the Academic Entrepreneur? The Role of Graduate Students in the Development of University Spinoffs', Journal of Technology Transfer, 42, 1-18.

Hébert, R. F., and Link, A. N. (2009), A History of Entrepreneurship, London, Routledge.

Hisrich, R. D., and Al-Dabbagh, A. (2012), Governpreneurship: Establishing a Thriving Entrepreneurial Spirit in Government, Cheltenham, Edward Elgar.

Holcombe, R. G. (2002), 'Political Entrepreneurship and the Democratic Allocation of Economic Resources', Review of Austrian Economics, 15, 143-59.

Hughes, J. (1991), 'Public Sector Entrepreneurship', in P. Higonnet, D. S. Landes, and H. Rosovsky (eds), Favorites of Fortune: Technology, Growth, and Economic Development since the Industrial Revolution, Cambridge, MA, Harvard University Press, 297-321.

Jones, P. (1978), 'The Appeal of the Political Entrepreneur', British Journal of Political Science, 8, 498-504.

Khan, B. Z. (2015), 'Inventing Prizes: A Historical Perspective on Innovation Awards and Technology Policy', Working Paper 21375, NBER Working Paper Series.

Kingdon, J. W. (1984), Agenda, Alternatives, and Public Policies, New York, Longman.

Kirchheimer, D. W. (1989), 'Public Entrepreneurship and Sub-National Government', Polity, 22, $108-22$.

Klein, P. G., Mahoney, J. T., McGahan, A. M., and Pitelis, C. N. (2009), 'Toward a Theory of Public Entrepreneurship', Working Paper 09-0106, College of Business, University of Illinois at Urbana-Champaign.

Klein, P. G., Mahoney, J. T., McGahan, A. M., and Pitelis, C. N.(2011), 'Resources, Capabilities, and Routines in Public Organization', Working Paper 11-0101, College of Business, University of Illinois at Urbana-Champaign.

Lanahan, L., and Feldman, M. P. (2015), 'Multilevel Innovation Policy Mix: A Closer Look at State Policies that Augment the Federal SBIR Program', Research Policy, 44, 1387-402.

León, L. R., Simmonds, P., and Roman, L. (2012), Trends and Challenges in Public Sector Innovation in Europe, technopolis |group|, Brussels.

Leyden, D. P., and Link, A. N. (2015), Public Sector Entrepreneurship: US Technology and Innovation Policy, New York, Oxford University Press.

Link, A. N., and Link, J. R. (2009), Government as Entrepreneur, Oxford, Oxford University Press.

Scott, J. T. (2007), 'The Economics of University Research Parks', Oxford Review of Economic Policy, 23(4), 661-74.

(2010), 'Government as Entrepreneur: Evaluating the Commercialization Success of SBIR Projects', Research Policy, 39, 589-601. 
(2012), Employment Growth from Public Support of Innovation in Small Firms, Kalamazoo, MI, W. E. Upjohn Institute for Employment Research.

Siegel, D. S., and van Fleet, D. (2011), 'Public Science and Public Innovation: Assessing the Relationship between Patenting at US National Laboratories and the Bayh-Dole Act', Research Policy, 40, 1094-9.

Moon, M. J. (1999), 'The Pursuit of Managerial Entrepreneurship: Does Organization Matter?', Public Administration Review, 59, 31-43.

Morris, M. H., and Jones, F. F. (1999), 'Entrepreneurship in Established Organizations: The Case of the Public Sector', Entrepreneurship Theory \& Practice, 24, 71-91.

Mowery, D. C., Nelson, R. R., Sampat, B. N., and Ziedonis, A. A. (2004), The Ivory Tower and Industrial Innovation: University-Technology Transfer Before and After the Bayh-Dole Act in the United States, Stanford, CA, Stanford University Press.

NRC (2016), SBIR at NASA, National Research Council, Washington, DC, National Academies Press.

Oakerson, R. J., and Parks, R. B. (1988), 'Citizen Voice and Public Entrepreneurship: The Organizational Dynamic of a Complex Metropolitan County’, Publius: The Journal of Federalism, 18, 91-112.

OECD (2015), The Innovation Imperative in the Public Sector: Setting an Agenda for Action, Paris, OECD Publishing.

- (2017), Fostering Innovation in the Public Sector, Paris, OECD Publishing.

Office of Science and Technology Policy (2014), Implementation of Federal Prize Authority: Fiscal Year 2013 Progress Report, Executive Office of the President of the United States.

Osborne, D., and Gaebler, T. (1992), Reinventing Government: How the Entrepreneurial Spirit is Transforming the Public Sector, New York, Addison-Wesley.

Ostrom, E. (1964), 'Public Entrepreneurship: A Case Study in Ground Water Basin Management', University of California, Los Angeles, CA, unpublished $\mathrm{PhD}$ dissertation. (2005), 'Unlocking Public Entrepreneurship and Public Economies', Working Paper DP2005/01, World Institute for Development Economic Research.

Padt, F. J. G., and Luloff, A. E. (2011), 'A Critical Review of a Managerial Approach to Green Community Planning in the Rural USA and the Netherlands', Journal of Environmental Planning and Management, 54, 445-56.

President's 2004 Budget (2003), available at: https://www.gpo.gov/fdsys/browse/collection.action?collectionCode=BUDGET\&browse $\underline{\text { Path}}=$ Fiscal + Year $+2004 \&$ isCollapsed $=$ false \&leafLevelBrowse $=$ false \&isDocumentResult $\underline{\mathrm{s}=\text { true \&ycord }=0}$

Ramamurti, R. (1986), 'Public Entrepreneurs: Who They Are and How They Operate', California Management Review, 28, 142-58. 
Roberts, N. C. (1992), 'Public Entrepreneurship and Innovation', Policy Studies Review, 11, $55-74$.

Sadler, R. J. (2000), 'Corporate Entrepreneurship in the Public Sector: The Dance of the Chameleon', Australian Journal of Public Administration, 59, 25-43.

Sampat, B. N. (2006), 'Patenting and US Academic Research in the 20th Century: The World Before and After Bayh-Dole', Research Policy, 35, 772-89.

Schneider, M., and Teske, P. (1992), 'Toward a Theory of the Political Entrepreneur: Evidence from Local Government', American Political Science Review, 86, 737-47.

Mintrom, M. (1995), Public Entrepreneurs: Agents for Change in American Government, Princeton, NJ, Princeton University Press.

Schnellenbach, J. (2007), 'Public Entrepreneurship and the Economics of Reform', Journal of Institutional Economics, 3, 183-202.

Schumpeter, J. A. (1942), Capitalism, Socialism and Democracy, New York, Harper \& Row.

Shane, S. (2004), Academic Entrepreneurship: University Spinoffs and Wealth Creation, New York, Edward Elgar.

Shockley, G. E., Stough, R. R., Haynes, K. E., and Frank, P. M. (2006), 'Toward a Theory of Public Sector Entrepreneurship', International Journal of Entrepreneurship and Innovation, Management, 6, 205-23.

Siegel, D. S., Waldman, D. A., Atwater, L., and Link, A. N. (2004), 'Toward a Model of the Effective Transfer of Scientific Knowledge from Academicians to Practitioners: Qualitative Evidence from the Commercialization of University Technologies', Journal of Engineering and Technology Management, 21, 115-42.

So, A. D., Sampat, B. N., Rai, A. K., Cook-Deegan, R., Reichman, J. H., et al. (2008), 'Is BayhDole Good for Developing Countries? Lessons from the US Experience', Public Library of Science Biology, 6, 2078-84.

Stine, D. S. (2009), 'Federally Funded Innovation Inducement Prizes', Congressional Research Service Report 7-5700, Washington, DC.

Wagner, R. E. (1966), 'Pressure Groups and Political Entrepreneurs: A Review Article', Public Choice, 1, 161-70.

Wessner, C. W. (2008), Assessment of the SBIR Program, Washington, DC, National Academies Press.

Zampetakis, L. A., and Moustakis, V. S. (2010), 'An Exploratory Research on the Factors Stimulating Corporate Entrepreneurship in the Greek Public Sector', International Journal of Manpower, 31, 871-87.

Zerbinati, S., and Souitaris, V. (2005), 'Entrepreneurship in the Public Sector: A Framework of Analysis in European Local Governments', Entrepreneurship and Regional Development: An International Journal, 17, 43-64. 